\title{
IMPLEMENTASI PROGRAM ADIWIYATA BERBASIS PARTISIPATIF DALAM MENUMBUHKAN NILAI-NILAI KARAKTER DI SEKOLAH DASAR
}

\author{
Tantri Nur Aini* \\ Sa'dun Akbar \\ Sri Estu Winahyu \\ Pendidikan Guru Sekolah Dasar, Jurusan Kependidikan Sekolah Dasar dan Pra Sekolah, \\ Fakultas Ilmu Pendidikan, Universitas Negeri Malang - JL. Semarang No 5 Malang, Indonesia \\ *E-mail: tantriaini18@gmail.com
}

Artikel diterima: 26 Juni 2020; disetujui: 31 Mei 2021

\begin{abstract}
This study aims to describe the implementation and character values that grow in students through the participatory-based Adiwiyata program at SDN Bareng 3 Malang. This research uses a qualitative approach with a descriptive research type. Data collection techniques in research are interviews, observation, and documentation. The results showed that SDN Bareng 3 Malang has implemented a participatory-based Adiwiyata program under the standards of participatory-based environmental activities. The activities include (a) maintenance and maintenance of the school building and environment; (b) participating in environmental action activities with outside parties; (c) forge partnerships and utilize sources from various parties to enhance environmental learning. As for the character values that grow in students of SDN Bareng 3 Malang, namely cooperation, caring for the environment, being independent, creative, disciplined, nationalist, religious, and responsible.
\end{abstract}

Keywords: participatory-based Adiwiyata program; character values; elementary school

\begin{abstract}
Abstrak: Penelitian ini bertujuan untuk mendeskripsikan implementasi dan nilai-nilai karakter yang tumbuh pada diri siswa melalui program Adiwiyata berbasis partisipatif di SDN Bareng 3 Malang. Penelitian ini menggunakan pendekatan kualitatif dengan jenis penelitian deskriptif. Teknik pengumpulan data dalam penelitian adalah wawancara, observasi, dan dokumentasi. Hasil penelitian menunjukkan bahwa SDN Bareng 3 Malang telah mengimplementasikan program Adiwiyata berbasis partisipatif sesuai dengan standar kegiatan lingkungan berbasis partisipatif. Bentuk kegiatannya yaitu, (a) pemeliharaan serta perawatan gedung dan lingkungan sekolah; (b) mengikuti kegiatan aksi peduli lingkungan bersama pihak luar; (c) menjalin kemitraan dan memanfaatkan sumber dari berbagai pihak untuk meningkatkan pembelajaran lingkungan hidup. Adapun nilai karakter yang tumbuh pada diri siswa SDN Bareng 3 Malang, yaitu gotong royong, peduli lingkungan, mandiri, kreatif, disiplin, nasionalis, religius, dan tanggung jawab.
\end{abstract}

Kata kunci: program Adiwiyata berbasis partisipatif; nilai-nilai karakter; sekolah dasar 


\section{PENDAHULUAN}

Isu tentang permasalahan lingkungan hidup menjadi topik yang sering diperbincangkan di era globalisasi ini. Perilaku manusia dalam berinteraksi dengan lingkungan menjadi salah satu penyebab utama munculnya permasalahan lingkungan. Salah satunya, perubahan iklim dunia yang ekstrim sebagai dampak dari kerusakan hutan, polusi udara, tanah dan air terjadi di berbagai tempat. Perilaku eksploitasi dalam memanfaatkan sumber daya alam dan berbagai proses industri maupun pembangunan tidak ramah lingkungan adalah contoh nyatanya (Aldyan, 2020). Peristiwa tersebut menunjukkan bahwa perilaku peduli manusia terhadap lingkungan masih rendah (Azmi \& Elfayetti, 2017).

Tanpa disadari, perilaku tidak peduli terhadap lingkungan menjadi kebiasaan yang mengakar mulai dari anak-anak hingga dewasa. Pernyataan ini didukung fakta hasil penelitian Akbar (2011) bahwa di beberapa SD Jawa Timur masih terdapat perilaku-perilaku siswa yang kurang baik bahkan tidak diharapkan terhadap lingkungannya yang menunjukkan bahwa perilaku peduli lingkungan dalam diri siswa sekolah dasar masih rendah. Penelitian lain oleh Narut \& Nardi (2019) pada empat sekolah dasar sebagai sampel menunjukkan bahwa meskipun siswa memiliki kesadaran dan perasaan terkait masalah lingkungan namun sikap peduli lingkungannya berada pada kategori rendah dan tidak nampak pada perilaku sehari-harinya.

Kondisi ini menjadi tantangan bagi pendidikan yang tidak hanya mengajarkan aspek kognitif, namun juga menekankan aspek sikap atau afektif. Terlebih lagi untuk siswa SD, perlu adanya upaya menanamkan dan menumbuhkan nilai-nilai karakter pada diri seorang siswa sejak dini untuk membentuk generasi yang peduli dan sadar akan pentingnya lingkungan (Purwanti, 2017). Salah satu kegiatan yang dapat digunakan untuk menumbuhkan nilai-nilai karakter pada siswa yaitu melalui program Adiwiyata. Program Adiwiyata merupakan wujud dari pendidikan lingkungan yang diterapkan di sekolah (Pelita \& Widodo, 2020). Di dalam program Adiwiyata terdapat kegiatan yang berbasis partisipatif yang melibatkan seluruh warga sekolah dalam peduli dan menjaga lingkungan.

Penelitian terkait implementasi Adiwiyata di sekolah juga telah banyak dilakukan berkaitan dengan karakter peduli lingkungan. Penelitian Deswari \& Supardan, (2016) menunjukkan upaya peningkatan kepedulian lingkungan siswa sekolah dasar dapat dilakukan melalui budaya sekolah dan program Adiwiyata. Penelitian lain oleh Habibi (2019) menunjukkan implementasi program adiwiyata di sekolah dasar dalam membentuk karakter peduli lingkungan siswa melalui dua prinsip dasar, yaitu prinsip partisipatif,dan prinsip berkelanjutan. Selain itu, penelitian dari Rotari (2017) menyatakan bahwa program Adiwiyata dapat meningkatkan kepedulian lingkungan siswa. Program Adiwiyata dapat mengajarkan siswa untuk peduli terhadap lingkungan baik itu lingkungan sekolah maupun di lingkungan sekitar mereka. 
Merujuk pada implementasi program Adiwiyata di sekolah dasar, dilakukan studi awal yang menunjukkan bahwa terdapat beberapa SD di Kota Malang yang telah memperoleh predikat dan melaksanakan program Adiwiyata berbasis partisipatif salah satunya, yaitu SDN Bareng 3 Malang. SDN Bareng 3 Malang merupakan sekolah dasar yang telah memperoleh penghargaan sebagai sekolah Adiwiyata nasional di Kota Malang. SDN Bareng 3 Malang juga telah mengimplementasikan kegiatan Adiwiyata berbasis partisipatif baik di lingkungan sekolah maupun di luar lingkungan sekolah dalam upaya menumbuhkan nilai-nilai karakter pada diri siswa.

Menumbuhkan nilai-nilai karakter merupakan bagian dari visi dan misi pendidikan karakter yang juga wajib diterapkan di sekolah dasar. Sesuai dengan tujuan dari pendidikan karakter secara fundamental adalah untuk menumbuhkan sikap dan nilai-nilai moral pada diri seorang siswa agar mau melakukan suatu hal yang baik dan benar dalam kehidupannya (Mulyasa, 2012). Melalui pendidikan karakter, siswa diharapkan dapat menginternalisasikan nilai-nilai karakter dan akhlak yang baik. Sekolah dapat menyusun suatu program yang didalamya terdapat kegiatan-kegiatan untuk menumbuhkan nilai-nilai karakter yang baik salah satunya program Adiwiyata. Sebagaimana didukung dengan hasil-hasil penelitian yang menunjukkan adanya hubungan positif antara pengetahuan dan etika lingkungan dalam program Adiwiyata terhadap sikap peduli terhadap lingkungan (Adriansyah dkk., 2019; Agusta \& Noorhapizah, 2018; Azhar dkk., 2016).

Dari temuan studi awal dan hasil penelitian terdahulu, peneliti tertarik untuk melakukan penelitian mengenai implementasi program Adiwiyata berbasis partisipatif dalam menumbuhkan nilai-nilai karakter di SDN Bareng 3 Malang. Penelitian ini menarik dan layak untuk dilakukan karena merujuk pada keberhasilan SDN Bareng 3 dalam mengimplementasikan program Adiwiyata dan wujudnya dalam membentuk karakter peduli lingkungan. Hasil penelitian dapat menjadi model implementasi program Adiwiyata dalam menumbuhkan dan membiasakan sikap peduli lingkungan sejak dini bagi siswa sekolah dasar. Maka dirumuskan tujuan penelitian ini adalah untuk mendeskripsikan implementasi program Adiwiyata berbasis partisipatif dan mendeskripsikan nilai-nilai karakter yang tumbuh pada diri siswa melalui program Adiwiyata berbasis partisipatif di SDN Bareng 3 Malang.

\section{METODE}

Penelitian ini menggunakan pendekatan kualitatif dengan jenis penelitian deskriptif yang bertujuan untuk mendapatkan gambaran (deskripsi) tentang peran implementasi program Adiwiyata berbasis partisipatif dalam menumbuhkan nilai-nilai karakter di SDN Bareng 3 Malang. Penelitian ini dilaksanakan di SDN Bareng 3 Malang yang berlokasi di Jalan Kawi Selatan No. 20, Bareng, Kec. Klojen, Kota Malang. Pemilihan lokasi pada penelitian ini, karena SDN Bareng 3 Malang merupakan salah satu sekolah dasar yang telah memperoleh penghargaan Sekolah 
Adiwiyata di tingkat Nasional dan telah melaksanakan program-program Adiwiyata berbasis partisipatif. Waktu pelaksanaan penelitian, yaitu pada bulan Februari-Maret tahun ajaran 2019/2020.

Sumber data pada penelitian ini meliputi kepala sekolah, guru atau koordinator Adiwiyata sekolah, siswa, orangtua siswa, dan dokumen-dokumen yang berkaitan dengan pelaksanaan program Adiwiyata berbasis partisipatif di SDN Bareng 3 Malang. Teknik pengumpulan data yang digunakan dalam penelitian ini meliputi wawancara, observasi, dan dokumentasi. Uji keabsahan data dilakukan dengan menggunakan empat metode yaitu kredibilitas dengan cara triangulasi sumber, transferabilitas, reliabilitas, dan obyektivitas.

\section{HASIL DAN PEMBAHASAN}

\section{Implementasi Program Adiwiyata Berbasis Partisipatif}

SDN Bareng 3 Malang dalam melaksanakan program Adiwiyata melibatkan seluruh warga sekolah, karena pelaksanaan program Adiwiyata merupakan tanggung jawab warga sekolah bersama. Hal ini diperlukan agar sikap, perilaku, dan karakter peduli lingkungan tumbuh dalam setiap diri warga sekolah. Sesuai dengan penjelasan dari Kementerian Lingkungan Hidup dan Kementerian Pendidikan Nasional dan Kebudayaan (2011:3) tujuan dari program Adiwiyata adalah mewujudkan warga sekolah yang bertanggung jawab dalam upaya perlindungan dan pengelolan lingkungan hidup melalui tata kelola sekolah yang baik untuk mendukung pembangunan berkelanjutan. Salah satu komponen program untuk mencapai Adiwiyata yang dilaksanakan oleh SDN Bareng 3 Malang adalah kegiatan lingkungan berbasis partisipatif.

Program Adiwiyata berbasis partisipatif melibatkan seluruh warga sekolah, orangtua siswa, dan masyarakat sekitar dalam mewujudkan sekolah peduli dan berbudaya lingkungan. Program Adiwiyata berbasis partisipatif dilaksanakan sesuai dengan standar kegiatan lingkungan berbasis partisipatif yang telah ditentukan oleh Kementerian Lingkungan Hidup bekerjasama dengan Kementerian Pendidikan dan Kebudayaan dalam buku panduan Adiwiyata (Deswari \& Supardan, 2016). Pada panduan dijelaskan bahwa standar kegiatan lingkungan berbasis partisipatif dilakukan dengan melaksanakan perlindungan dan pengelolaan lingkungan hidup yang terencana bagi seluruh warga sekolah dalam berbagai bentuk kegiatan. Kegiatan tersebut dapat berupa pembiasaan, keteladanan, dan pembinaan yang terintegrasi dalam pembelajaran maupun melalui kegiatan rutin (Wardani, 2020).

Hasil penelitian menunjukkan bahwa SDN Bareng 3 Malang mengimplementasikan program Adiwiyata berbasis partisipatif sesuai standar yang telah ditentukan. Terdapat tiga kegiatan yang telah dilaksanakan oleh SDN Bareng 3 Malang dalam mengimplementasikan program Adiwiyata berbasis partisipatif. Pertama, melaksanakan kegiatan pemeliharaan serta perawatan gedung dan 
lingkungan sekolah. Kedua, mengikuti kegiatan aksi peduli lingkungan yang dilaksanakan oleh pihak luar. Ketiga, melaksanakan kegiatan menjalin kemitraan dan memanfaatkan narasumber dari berbagai pihak untuk meningkatkan pembelajaran lingkungan hidup. Berikut uraian masingmasing kegiatan tersebut.

\section{Kegiatan Pemeliharaan Serta Perawatan Gedung dan Lingkungan Sekolah}

SDN Bareng 3 Malang melaksanakan kegiatan pemeliharaan serta perawatan gedung dan lingkungan sekolah dalam bentuk kegiatan Jumat bersih dan lomba kebersihan kelas. Kegiatan Jumat bersih merupakan kegiatan pembiasaan rutin yang dilaksanakan oleh seluruh warga sekolah setiap hari Jumat, sedangkan kegiatan lomba kebersihan kelas dilaksanakan oleh SDN Bareng 3 Malang setiap satu tahun sekali untuk memperingati hari kemerdekaan Republik Indonesia atau untuk memperingati hari yang berkaitan dengan lingkungan hidup. Kegiatan pemeliharaan serta perawatan gedung dan lingkungan sekolah merupakan implementasi dari standar kegiatan lingkungan berbasis partisipatif yang pertama, yaitu standar pengelolaan lingkungan hidup yang terencana bagi warga sekolah. Gambar 1. Menunjukkan dokumentasi kegiatan pemeliharaan dan perawatan lingkungan sekolah di SDN Bareng 3 Kota Malang.
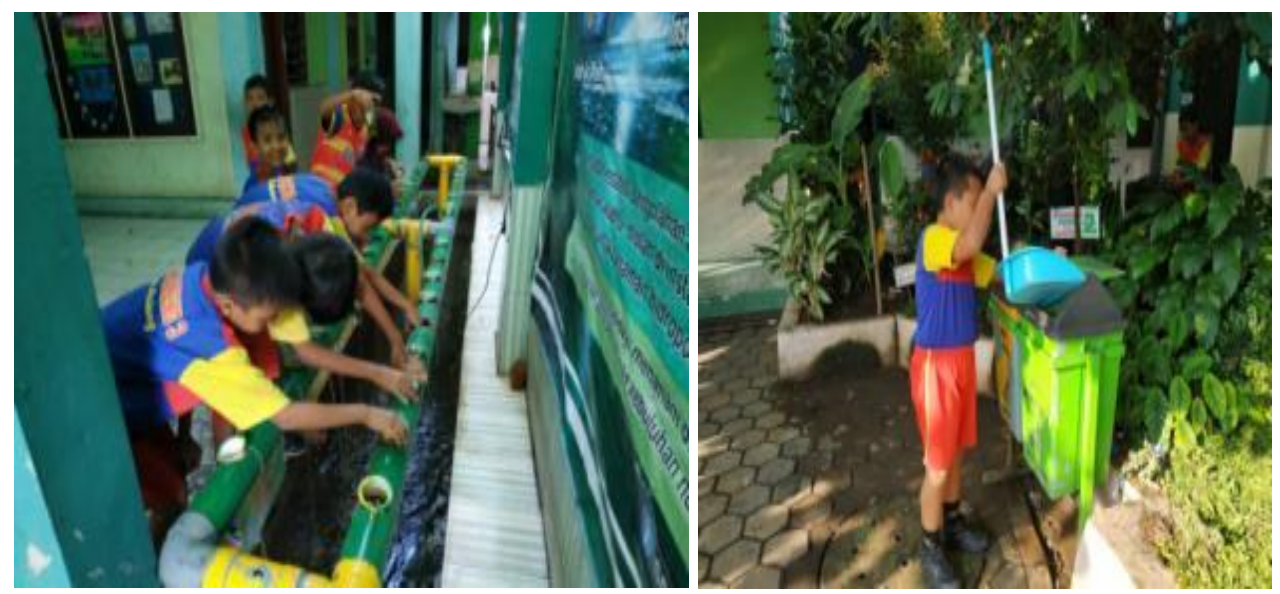

Gambar 1. Kegiatan Jumat Bersih di SDN Bareng 3 Kota Malang

Kegiatan ini merupakan bentuk pembudayaan di sekolah dalam mewujudkan sekolah yang peduli dan berbudaya lingkungan. Sekolah berusaha menerapkan pembiasaan yang baik melalui kegiatan dalam program Adiwiyata berbasis partisipatif dengan tujuan agar seluruh warga sekolah khususnya siswa dapat terbiasa menjaga dan peduli terhadap lingkungan sekitarnya. Pembiasaan inilah yang diharapkan dapat mewujudkan budaya peduli terhadap lingkungan dan karakter yang baik pada diri siswa (Andiarini dkk., 2018). Pembiasaan membawa perubahan positif pada sebuah perilaku dalam mengadaptasi dan mengadopsi sebuah perilaku dari waktu ke waktu secara berkelanjutan (Yudabangsa, 2020). 


\section{Kegiatan Aksi Peduli Lingkungan yang Dilaksanakan Oleh Pihak Luar}

Kegiatan program Adiwiyata berbasis partisipatif lain yang dilaksanakan oleh SDN Bareng 3 Malang, yaitu mengikuti kegiatan aksi peduli lingkungan hidup dari pihak luar. Ada beberapa kegiatan aksi peduli lingkungan yang pernah diikuti oleh SDN Bareng 3 Malang. Kegiatan tersebut adalah green school festival, aksi bersih sampah di sekitar alun-alun Kota Malang, kampanye peduli sampah bersama forum Adiwiyata Kota Malang, dan kegiatan kerja bakti dengan masyarakat sekitar sekolah. Gambar 2. menunjukkan hasil dokumentasi pelaksanaan kegiatan aksi peduli lingkungan dari sekolah.
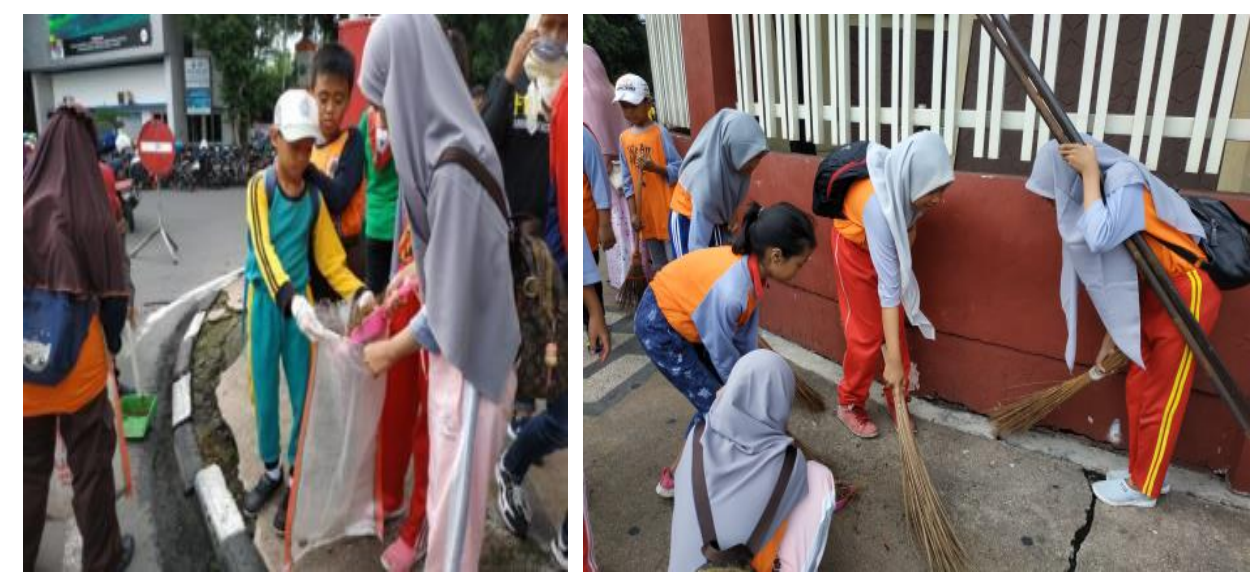

Gambar 2. Partisipasi SDN Bareng 3 Malang dalam Kegiatan Bersih-bersih Alun-alun

Mengikuti kegiatan aksi peduli lingkungan yang dilaksanakan oleh pihak luar juga merupakan implementasi dari standar pengelolaan lingkungan hidup yang terencana bagi warga sekolah. Melalui partisipasi pada kegiatan aksi peduli lingkungan yang ada di luar sekolah, siswa dapat belajar tentang kepedulian terhadap lingkungan sekitar mereka. Sesuai pendekatan berbasis masyarakat, mengikuti aksi peduli lingkungan hidup yang dilaksanakan oleh pihak luar dapat meningkatkan pembelajaran lingkungan hidup (Choiri, 2017). Kegiatan ini juga memberdayakan potensi lingkungan masyarakat sekitar sebagai sumber belajar yaitu memberikan wawasan pada siswa pada lingkungan sosial yang lebih luas selain keluarga dan sekolah. Siswa dapat belajar dari masyarakat sekitar, membangun kepedulian, dan menyadari hubungan sosial untuk saling berkontribusi dalam kepentingan bersama (Subiyakto \& Mutiani, 2019).

Kegiatan pembiasaan dan pembudayaan pada program Adiwiyata berbasis partisipatif yang dilaksanakan oleh SDN Bareng 3 Malang tidak hanya sebagai implementasi program Adiwiyata saja, tetapi juga sebagai bentuk upaya Penguatan Pendidikan Karakter (PPK) dan bertujuan untuk menumbuhkan nilai-nilai karakter pada diri siswa. Pendidikan karakter mempunyai makna lebih tinggi dari pendidikan moral, karena tidak hanya berbicara mengenai mana yang benar dan mana yang salah, tetapi lebih kepada bagaimana menanamkan kebiasaan tentang hal-hal yang baik pada siswa (Mulyasa, 2012). Dari kegiatan-kegiatan tersebut selain berpartisipasi dalam kegiatan 
Adiwiyata berbasis partisipatif, siswa juga dapat memperoleh pengetahuan baik yang akan menjadi kebiasaan baik untuk diterapkan dalam kehidupan sehari-hari. Hal tersebut seperti yang diungkapkan oleh bahwa pendidikan karakter dikembangkan melalui tahap pengetahuan, pelaksanaan, dan kebiasaan (Purwanti, 2017).

\section{Menjalin Kemitraan dan Memanfaatkan Narasumber Dari Berbagai Pihak}

Kegiatan menjalin kemitraan dan memanfaatkan narasumber dari berbagai pihak untuk meningkatkan pembelajaran lingkungan hidup juga merupakan implementasi dari program Adiwiyata berbasis partisipatif yang dilaksanakan oleh SDN Bareng 3 Malang. Kegiatan kemitraan yang pernah dilaksanakan oleh SDN Bareng 3 Malang, yaitu penyuluhan perilaku hidup bersih dan sehat bersama Puskesmas Bareng, pelatihan pembuatan sumur resapan dan biopori bersama Politeknik Negeri Malang, dan sosialisasi Adiwiyata pemanfaatan sampah anorganik sebagai bahan kerajinan tangan bersama PKK Kelurahan Pisang Candi. Kegiatan tersebut dilaksanakan dengan menjalin kemitraan dengan berbagai pihak secara partisipatif.

Selain pihak luar, kegiatan-kegiatan pada program Adiwiyata berbasis partisipatif juga didukung oleh orangtua siswa. Orangtua siswa memberikan dukungan kepada sekolah dengan berpartisipasi di dalam beberapa kegiatan Adiwiyata berbasis partisipatif. SDN Bareng 3 Malang memiliki kelompok wali murid Adiwiyata yang biasanya berpartisipasi dalam kegiat-kegiatan Adiwiyata. Orangtua siswa tidak hanya berpartisipasi dalam kegiatan tetapi juga ikut membantu berkomunikasi dengan pihak masyarakat atau instansi yang akan menjadi narasumber dalam kegiatan Adiwiyata. Gambar 3. menunjukkan partisipasi orangtua siswa dalam kegiatan Adiwiyata.

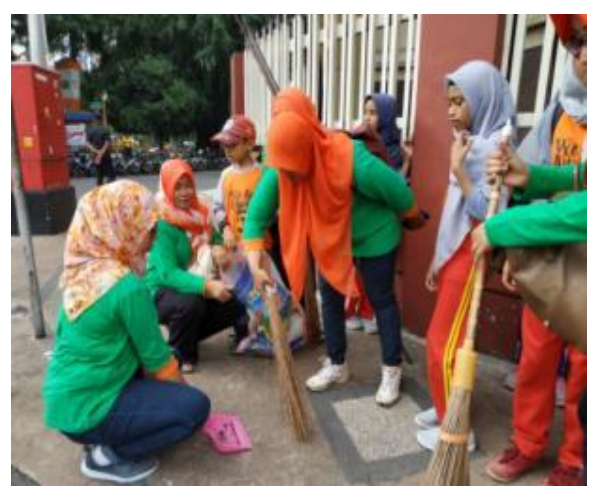

\section{Gambar 3. Orangtua Berpartisipasi pada Kegiatan Bersih-bersih Alun-alun}

Kegiatan menjalin kemitraan dan memanfaatkan narasumber dari berbagai pihak bertujuan untuk meningkatkan pembelajaran lingkungan hidup bagi siswa, sekolah, pihak-pihak terkait dan masyarakat sekitar seperti orang tua siswa. Bentuk dukungan dan partisipasi dari kelompok orang tua siswa memberikan kontribusi penting dalam mencapai tujuan pelaksanaan program sekolah (Patalatu \& Besare, 2020). Bentuk dukungan yang diberikan orangtua siswa di SDN Bareng 3 Kota Malang dengan membantu kerjasama sekolah, ikut menyumbangkan ide-ide dan inovasi 
mengenai kegiatan pengelolaan lingkungan hidup di sekolah menjadi indikator kesuksesan sekolah menyelenggarakan kegiatan Adiwiyata berbasis partisipatif (Junianto \& Wagiran, 2013). Hal inilah yang menjadi sasaran tidak langsung dalam program Adiwiyata sebagai model dalam membangun sikap peduli terhadap lingkungan dengan harapan setiap pihak yang terlibat dapat saling berbagi dan melakukan diseminasi praktik baik dalam menjaga kebersihan, kelestarian, dan pemanfaatan lingkungan (Desfandi, 2015).

Kegiatan dalam program Adiwiyata berbasis partisipatif yang dilaksanakan oleh SDN Bareng 3 Malang juga sesuai dengan pendekatan penguatan pendidikan karakter, yaitu pendekatan berbasis budaya sekolah dan masyarakat. Terdapat tiga pendekatan utama dalam mengimplementasikan penguatan karakter di sekolah, yaitu melalui pendekatan berbasis kelas, berbasis budaya sekolah, dan berbasis masyarakat (Andiarini dkk., 2018). Kegiatan berbasis kelas dan budaya sekolah dilakukan melalui pembiasaan nilai-nilai utama dalam keseharian sekolah dan keteladanan antar warga sekolah. Kegiatan berbasis masyarakat dengan melibatkan seluruh warga sekolah, orang tua siswa, lembaga dan masyarakat sekitar dalam membangun kebiasaan positif bersama.

\section{Nilai-nilai Karakter Pada Program Adiwiyata Berbasis Partisipatif}

Implementasi program Adiwiyata berbasis partisipatif yang dilaksanakan di SDN Bareng 3 Malang juga berperan untuk menumbuhkan nilai-nilai karakter pada diri siswa. Adapun nilai-nilai karakter yang tumbuh pada diri siswa melalui program Adiwiyata berbasis partisipatif di SDN Bareng 3 Malang, antara lain gotong royong, peduli lingkungan, mandiri, kreatif, nasionalis, religius, disiplin, dan bertanggung jawab. Berikut uraian nilai-nilai karakter tersebut.

\section{Gotong Royong}

Kegiatan program Adiwiyata berbasis partisipatif yang dapat menumbuhkan nilai karakter gotong royong yaitu kegiatan Jumat bersih, lomba kebersihan kelas, mengikuti aksi bersih alunalun Kota Malang, aksi kampanye peduli lingkungan, dan kerja bakti bersama masyarakat sekitar sekolah. Pada kegiatan-kegiatan tersebut nilai karakter gotong royong tampak ketika para siswa saling membantu dan bekerjasama untuk membersihkan lingkungan sekolah maupun lingkungan di luar sekolah. Nilai karakter gotong royong merupakan tindakan saling menghargai, semangat kerja sama, dan bahu membahu menyelesaikan persoalan bersama, menjalin komunikasi, serta memberi bantuan atau pertolongan pada orang lain (Mulyani dkk., 2020).

Kegiatan lain seperti Green School Festival, kegiatan sosialisasi Adiwiyata, pemanfaatan sampah anorganik sebagai bahan kerajinan tangan bersama PKK Kelurahan Pisang Candi, kegiatan pelatihan pembuatan sumur resapan dan biopori bersama Politeknik Negeri Malang, juga dapat menumbuhkan dan mengembangkan nilai karakter gotong royong. Pada kegiatan-kegiatan tersebut siswa dilatih untuk bekerjasama dengan siswa lain dalam menyelesaikan suatu pekerjaan. 
Melalui kegiatan-kegiatan tersebut, siswa juga dapat belajar tentang semangat kerjasama, saling menghargai, dan saling membantu dalam menyelesaikan suatu pekerjaan (Syahrial dkk., 2019).

\section{Peduli Lingkungan}

Kegiatan pada program Adiwiyata berbasis partisipatif, baik yang dilaksanakan di sekolah maupun di luar sekolah dapat menumbuhkan dan mengembangkan nilai karakter peduli lingkungan pada diri siswa. Pada kegiatan Jumat bersih, lomba kebersihan kelas, dan Green School Festival dapat menumbuhkan nilai peduli lingkungan di sekolah. Kegiatan aksi lingkungan yang dilaksanakan oleh pihak luar, seperti aksi bersih Alun-alun Kota Malang, kampanye peduli sampah, dan kegiatan kerja bakti di lingkungan sekitar sekolah juga dapat menumbuhkan nilai peduli lingkungan siswa terhadap lingkungan sekitar. Kegiatan sosialisasi Adiwiyata pemanfaatan sampah anorganik sebagai bahan kerajinan tangan bersama PKK Kelurahan Pisang Candi juga dapat menumbuhkan nilai karakter peduli lingkungan, melalui kegiatan tersebut siswa belajar untuk peduli terhadap lingkungan dengan memanfaatkan bahan bekas (Rotari, 2017).

Sikap dan perilaku siswa ketika di sekolah juga menunjukkan nilai karakter peduli lingkungan. Sikap dan perilaku tersebut tampak pada saat siswa beraktivitas di sekolah seperti, ketika siswa selalu membuang sampah pada tempatnya, siswa mengurangi penggunaan plastik dengan membawa bekal dari rumah atau tidak membeli makanan yang menggunakan kemasan plastik, dan ketika siswa melaksanakan piket setelah jam pembelajaran. Nilai karakter peduli lingkungan juga dikembangkan sebagai upaya untuk mencegah kerusakan pada lingkungan alam di sekitarnya, dan mengembangkan upaya-upaya untuk memperbaiki kerusakan alam yang telah terjadi (Adriansyah dkk., 2019).

\section{Mandiri}

Kegiatan Green School Festival pada program Adiwiyata berbasis partisipatif dapat menumbuhkan nilai karakter mandiri. Pada kegiatan tersebut siswa diminta untuk mencari informasi dan membuat mapping tentang isu-isu lingkungan. Siswa berusaha mandiri dalam menyelesaikan tugas dan mencari informasi yang terkait dengan isu-isu lingkungan di sekolah.

Nilai karakter mandiri tersebut juga tampak pada saat siswa mengelola dan menjalankan piket kelas setelah pembelajaran selesai. Aktivitas siswa inilah yang diharapkan dapat menjadi kebiasaan positif dari waktu ke waktu (Hamli Syaifullah, 2016). Hasil nyata dari pembiasaan tersebut ditunjukkan ketika siswa melaksanakan piket sesuai jadwal secara mandiri tanpa bantuan dari guru kelas. Hal ini sesuai dengan nilai karakter mandiri antara lain etos kerja, tangguh tahan banting, daya juang, profesional, kreatif, keberanian, dan menjadi pembelajar sepanjang hayat (Wulandari \& Azka, 2018). 


\section{Kreatif}

Program Adiwiyata berbasis partisipatif, yaitu Green School Festival dan kegiatan sosialisasi Adiwiyata pemanfaatan sampah anorganik sebagai bahan kerajinan tangan bersama PKK Kelurahan Pisang Candi dapat menumbuhkan nilai karakter kreatif pada diri siswa. Pada kegiatan green school festival siswa diminta untuk mencari isu-isu mengenai permasalahan lingkungan dan membuat mapping mengenai isu-isu lingkungan tersebut. Kegiatan ini juga sebagai salah satu sasaran dalam program Adiwiyata membuat inovasi-inovasi dalam mengatasi permasalahan lingkungan (Wardani, 2020). Pada kegiatan sosialisasi Adiwiyata pemanfaatan sampah anorganik sebagai bahan kerajinan tangan bersama PKK Kelurahan Pisang Candi, kreatifitas siswa dapat dilihat pada saat mereka mempraktekkan cara membuat piring atau rege dari bahan botol plastik bekas. Melalui kegiatan-kegiatan tersebut kreativitas siswa dapat dilatih dan dikembangkan yakni dalam berpikir dan melakukan sesuatu untuk menghasilkan cara atau hasil baru dari sesuatu yang telah dimiliki (Rachmadyanti, 2017).

\section{Nasionalis}

Kegiatan kampanye peduli sampah, kegiatan aksi bersih-bersih alun-alun Kota Malang, dan kegiatan kerja bakti dengan masyarakat sekitar dalam rangka memperingati HUT kemerdekaan Indonesia merupakan kegiatan yang dapat menumbuhkan nilai karakter nasionalis pada diri siswa. Pada kegiatan tersebut siswa belajar untuk menjaga dan merawat lingkungan sekolahnya. Sikap peduli terhadap lingkungan sekitarnya juga menunjukkan kepedulian dan cinta terhadap bangsanya. Kegiatan ini dapat menjadi contoh sederhana menumbuhkan rasa nasionalisme apalagi dengan maraknya berbagai isu-isu budaya asing yang dapat melemahkan rasa cinta tanah air (Erviana, 2021). Partisipasi siswa pada kegiatan-kegiatan tersebut menunjukkan kepedulian mereka terhadap lingkungan sekitar dan bangsanya. Secara tidak langsung perilaku siswa menunjukkan kesetiaan, kepedulian, dan penghargaan yang tinggi terhadap bangsa, lingkungan fisik, sosial, budaya, ekonomi, dan politik bangsa sebagai bentuk rasa nasionalisme (Handayani dkk., 2015).

\section{Religius}

Kegiatan yang terdapat pada program Adiwiyata berbasis partisipatif juga dapat menumbuhkan nilai karakter religius. Nilai karakter religius tidak hanya berkaitan tentang hubungan manusia dengan keyakinannya, tetapi juga meliputi hubungan individu dengan sesama manusia, dan individu dengan lingkungan atau alam (Suyitno, 2018). Kegiatan pada program Adiwiyata seperti Jumat bersih, lomba kebersihan kelas, aksi bersih Alun-alun Kota Malang, kampanye peduli sampah, dan kerja bakti bersama masyarakat sekitar sekolah, mengajarkan siswa agar senantiasa menjaga kebersihan dan peduli terhadap lingkungan sekitar sebagai wujud implementasi nilai religius pada dirinya. Pada kondisi inilah sekolah perlu menyadari peran 
sekolah dalam membentuk karakter religius siswa dengan memberikan penguatan terhadap perilaku positif siswa (Silkyanti, 2019).

\section{Disiplin}

Pelaksanaan program Adiwiyata berbasis partisipatif di sekolah menjadikan siswa disiplin dalam menjaga dan merawat kebersihan lingkungan sekolah. Nilai karakter disiplin pada siswa dapat dilihat pada perilaku siswa di sekolah seperti menaati peraturan untuk membuang sampah pada tempatnya, selalu mencuci tangan, tidak jajan sembarangan di luar sekolah, membawa bekal atau membeli makanan di kantin sehat sekolah untuk mengurangi sampah plastik di sekolah, dan melaksanakan piket sesuai dengan jadwal. Perilaku tersebut menjadi indikator karakter disiplin yang menekankan pada ketertiban dan kepatuhan siswa dalam berperilaku. Sesuai hasil penelitian Annisa (2019) dalam menginternalisasikan karakter disiplin dibutuhkan sebuah program, pembiasaan, pendampingan, dan melibatkan orangtua serta masyarakat sekitar.

\section{Tanggung jawab}

Kegiatan-kegiatan dalam program Adiwiyata berbasis partisipatif juga dapat menumbuhkan karakter tanggung jawab pada siswa. Pada kegiatan Jumat bersih siswa dilatih dan belajar bertanggung jawab untuk menjaga kebersihan lingkungan sekolah dengan merawat dan membersihkan lingkungan sekolah sesuai arahan dari guru. Sikap dan perilaku bertanggung jawab juga tampak ketika siswa melaksanakan piket sesuai jadwal masing-masing. SDN Bareng 3 Malang sebagai sekolah Adiwiyata juga menerapkan punishment atau hukuman yang berwawasan lingkungan untuk menanamkan nilai karakter tanggung jawab pada diri siswa. Punishment merupakan bentuk penguatan yang bersifat preventif dan kuratif terhadap perilaku negatif siswa bahkan memungkinkan menimbulkan perubahan baik karena efek jera (Shen \& Chi, 2016). Contoh dari punishment berwawasan lingkungan yang dilakukan oleh SDN Bareng 3 Malang, yaitu pada saat siswa terlambat siswa diminta mengumpulkan 30 sampah di lingkungan sekolah sebelum masuk ke kelas. Karakter tanggung jawab akan membentuk sikap siswa untuk memahami hak dan kewajibannya terhadap diri sendiri, masyarakat, lingkungan (alam, sosial dan budaya), negara dan Tuhan Yang Maha Esa (Barnes dkk., 2021).

\section{SIMPULAN DAN SARAN}

\section{Simpulan}

Implementasi program Adiwiyata berbasis partisipatif di SDN Bareng 3 Malang dilaksanakan dengan melibatkan peran serta seluruh warga sekolah, orangtua siswa, masyarakat dan mitra instansi terkait pembelajaran lingkungan hidup. Implementasi program Adiwiyata berbasis partisipatif telah sesuai dengan standar kegiatan lingkungan berbasis partisipatif. SDN Bareng 3 Malang mengimplementasikan program Adiwiyata berbasis partisipatif melalui beberapa jenis 
kegiatan yaitu (1) kegiatan pemeliharaan serta perawatan gedung dan lingkungan sekolah, (2) mengikuti kegiatan aksi peduli lingkungan yang dilaksanakan oleh pihak luar, dan (3) kegiatan menjalin kemitraan dan memanfaatkan narasumber dari berbagai pihak untuk meningkatkan pembelajaran lingkungan hidup. Program Adiwiyata berbasis partisipatif tidak hanya bertujuan untuk menjadikan sekolah peduli dan berbudaya lingkungan saja, tetapi juga bertujuan untuk menumbuhkan nilai-nilai karakter pada diri siswa. Nilai-nilai karakter dapat dikembangkan melalui kegiatan pada program Adiwiyata berbasis partisipatif. Adapun nilai karakter yang tumbuh pada disi siswa SDN Bareng 3 Malang, yaitu gotong royong, peduli lingkungan, mandiri, kreatif, disiplin, nasionalis, religius, dan tanggung jawab.

\section{Saran}

Dari hasil penelitian ini disarankan bagi sekolah dasar baik guru, kepala sekolah, orang tua, maupun pihak terkait untuk dapat mengoptimalkan pelaksanaan program Adiwiyata dalam menumbuhkan karakter peduli lingkungan siswa sejak dini. Disarankan juga bagi peneliti selanjutnya untuk dapat meneliti lebih dalam dan pada sekolah lain tentang implementasi program Adiwiyata pada kegiatan pembelajaran di kelas yang berkaitan dengan upaya menumbuhkan nilainilai karakter pada diri siswa sekolah dasar.

\section{DAFTAR RUJUKAN}

Adriansyah, M. A., Sofia, L., \& Rifayanti, R. (2019). Pengaruh Pelatihan Pendidikan Lingkungan Hidup Terhadap Sikap Peduli Anak Akan Kelestarian Lingkungan. Psikostudia: Jurnal Psikologi, 5(2), 86. https://doi.org/10.30872/psikostudia.v5i2.2281

Agusta, A. R., \& Noorhapizah, Dr. (2018). Improving the Student's Cooperation and Environmental Care Skill using Outdoor Learning Strategy Outbound Variation. Proceedings of the 1st International Conference on Creativity, Innovation and Technology in Education (IC-CITE 2018). Proceedings of the 1st International Conference on Creativity, Innovation and Technology in Education (IC-CITE 2018), Banjarmasin, Indonesia. https://doi.org/10.2991/iccite-18.2018.3

Akbar, S. (2011). Revitalisasi Pendidikan Karakter di Sekolah Dasar. Naskah Pengukuhan Guru Besar, Universitas Negeri Malang.

Aldyan, R. A. (2020). The Effect of Globalization and Capitalism on Forest Damage in Indonesia. Diadikasia Journal, 1(1). https://doi.org/10.21428/8c841009.0f98753e

Andiarini, S. E., Arifin, I., \& Nurabadi, A. (2018). Implementasi Program Penguatan Pendidikan Karakter Melalui Kegiatan Pembiasaan Dalam Peningkatan Mutu Sekolah. Jurnal Administrasi Dan Manajemen Pendidikan, 1(2), 238-244. https://doi.org/10.17977/um027v1i22018p238

Annisa, F. (2019). Penanaman Nilai-Nilai Pendidikan Karakter Disiplin Pada Siswa Sekolah Dasar: Inserting of Discipline Character Education Values in Basic School Students. Perspektif $\begin{array}{llll}\text { Pendidikan Dan } & \text { Keguruan, }\end{array}$ https://doi.org/10.25299/perspektif.2019.vol10(1).3102 
Azhar, A., Basyir, M. D., \& Alfitri, A. (2016). Hubungan Pengetahuan Dan Etika Lingkungan Dengan Sikap dan Perilaku Menjaga Kelestarian Lingkungan. Jurnal Ilmu Lingkungan, 13(1), 36. https://doi.org/10.14710/jil.13.1.36-41

Azmi, F., \& Elfayetti, E. (2017). Analisis Sikap Peduli Lingkungan Siswa Melalui Program Adiwiyata Di SMA Negeri 1 Medan. JURNAL GEOGRAFI, 9(2), 125. https://doi.org/10.24114/jg.v9i2.6901

Barnes, M. A., Davis, C., Kulesz, P., \& Francis, D. (2021). Effects of semantic reinforcement, semantic discrimination, and affix frequency on new word learning in skilled and less skilled readers in Grades 6 to 12. Journal of Experimental Child Psychology, 205, 105083. https://doi.org/10.1016/j.jecp.2020.105083

Choiri, Moh. M. (2017). Upaya Pemanfaatan Lingkungan Sekitar Sebagai Sumber Belajar Anak. Refleksi Edukatika: Jurnal Ilmiah Kependidikan, 8(1). https://doi.org/10.24176/re.v8i1.1793

Desfandi, M. (2015). Mewujudkan Masyarakat Berkarakter Peduli Lingkungan Melalui Program Adiwiyata. SOSIO DIDAKTIKA: Social Science Education Journal, 2(1), 31-37. https://doi.org/10.15408/sd.v2i1.1661

Deswari, N., \& Supardan, D. (2016). Upaya Peningkatan Environmental Literacy Peserta Didik Di Sekolah Adiwiyata (Studi Inkuiri Naturalistik Di Sd Negri 138 Pekanbaru). Jurnal Socius, 5(2). https://doi.org/10.20527/jurnalsocius.v5i2.3331

Diyan Nurvika Kusuma Wardani. (2020). Analisis Implementasi Program Adiwiyata dalam Membangun Karakter Peduli Lingkungan. Southeast Asian Journal of Islamic Education Management, 1(1), 60-73. https://doi.org/10.21154/sajiem.v1i1.6

Erviana, V. Y. (2021). Penanganan Dekadensi Moral melalui Penerapan Karakter Cinta Damai dan Nasionalisme. Jurnal Penelitian Ilmu Pendidikan, 14(1), 1-9. https://doi.org/10.21831/jpipfip.v14i1.27149

Habibi, M. W. (2019). Implementasi Program Adiwayata Dalam Membentuk Karakter Peduli Lingkungan Pada Siswa: Studi multi situs di SD Insan Amanah dan SDU Al-Ya'lu Kota Malang. Doctoral dissertation, Universitas Islam Negeri Maulana Malik Ibrahim. http://etheses.uin-malang.ac.id/14199/.

Hamli Syaifullah, S. R. (2016). Optimalisasi Pendidikan Karakter Untuk Menumbuh Kembangkan Kemandirian Anak Berkebutuhan Khusus (Abk). Nadwa, 6(1), 179. https://doi.org/10.21580/nw.2012.6.1.463

Handayani, T., Wuryadi, W., \& Zamroni, Z. (2015). Pembudayaan Nilai Kebangsaan Siswa Pada Pendidikan Lingkungan Hidup Sekolah Dasar Adiwiyata Mandiri. Jurnal Pembangunan Pendidikan: Fondasi Dan Aplikasi, 3(1), 95-105. https://doi.org/10.21831/jppfa.v3i1.7815

Junianto, D., \& Wagiran, W. (2013). Pengaruh kinerja mengajar guru, keterlibatan orang tua, aktualisasi diri dan motivasi berprestasi terhadap prestasi. Jurnal Pendidikan Vokasi, 3(3). https://doi.org/10.21831/jpv.v3i3.1845

Mulyani, D., Ghufron, S., Akhwani, A., \& Kasiyun, S. (2020). Peningkatan Karakter Gotong Royong di Sekolah Dasar. Lectura: Jurnal Pendidikan, 11(2), 225-238. https://doi.org/10.31849/lectura.v11i2.4724

Mulyasa, E. (2012). Manajemen Pendidikan Karakter. PT. Remaja Rosdakarya Offset.

Narut, Y. F., \& Nardi, M. (2019). Analisis Sikap Peduli Lingkungan Pada Siswa Kelas VI Sekolah Dasar di Kota Ruteng. Scholaria: Jurnal Pendidikan Dan Kebudayaan, 9(3), 259-266. https://doi.org/10.24246/j.js.2019.v9.i3.p259-266 
Patalatu, J. S., \& Besare, S. D. (2020). Pengaruh Pola Asuh Orang Tua terhadap Sikap Peduli Sampah pada Anak. Sekolah Dasar: Kajian Teori Dan Praktik Pendidikan, 29(1), 19-27. https://doi.org/10.17977/um009v29i12020p019

Pelita, A. C., \& Widodo, H. (2020). Evaluasi Program Sekolah Adiwiyata di Sekolah Dasar Muhammadiyah Bantul Kota. Sekolah Dasar: Kajian Teori Dan Praktik Pendidikan, 29(2), 145-157. https://doi.org/10.17977/um009v29i22020p145

Purwanti, D. (2017). Pendidikan Karakter Peduli Lingkungan Dan Implementasinya. Dwija Cendekia: Jurnal Riset Pedagogik, 1(2). https://doi.org/10.20961/jdc.v1i2.17622

Rachmadyanti, P. (2017). PENGUATAN PENDIDIKAN KARAKTER BAGI SISWA SEKOLAH DASAR MELALUI KEARIFAN LOKAL. Jurnal Pendidikan Sekolah Dasar, 3(2), 201. https://doi.org/10.30870/jpsd.v3i2.2140

Rotari, S. (2017). Peran Program Adiwiyata Mandiri dalam Meningkatkan Kepedulian Lingkungan Peserta Didik. Citizenship Jurnal Pancasila Dan Kewarganegaraan, 5(1), 42. https://doi.org/10.25273/citizenship.v5i1.1177

Shen, S., \& Chi, M. (2016). Reinforcement Learning: The Sooner the Better, or the Later the Better? Proceedings of the 2016 Conference on User Modeling Adaptation and Personalization, 37-44. https://doi.org/10.1145/2930238.2930247

Silkyanti, F. (2019). Analisis Peran Budaya Sekolah yang Religius dalam Pembentukan Karakter Siswa. Indonesian Values and Character Education Journal, 2(1), 36. https://doi.org/10.23887/ivcej.v2i1.17941

Subiyakto, B., \& Mutiani, M. (2019). Internalisasi Nilai Pendidikan Melalui Aktivitas Masyarakat Sebagai Sumber Belajar Ilmu Pengetahuan Sosial. Khazanah: Jurnal Studi Islam Dan Humaniora, 17(1), 137. https://doi.org/10.18592/khazanah.v17i1.2885

Suyitno, S. (2018). Strategi Pembentukan Budaya Religius di SD Muhammadiyah Wirobrajan 3 Yogyakarta. Edukasi Journal, 10(2), 191-204. https://doi.org/10.31603/edukasi.v10i2.2310

Syahrial, S., Kurniawan, A. R., Alirmansyah, A., \& Alazi, A. (2019). Strategi Guru dalam Menumbuhkan Nilai Kebersamaan pada Pendidikan Multikultural di Sekolah Dasar. Jurnal Gentala Pendidikan Dasar, 4(2), 232-244. https://doi.org/10.22437/gentala.v4i2.8455

Wulandari, E., \& Azka, R. (2018). Menyambut Pisa 2018: Pengembangan Literasi Matematika Untuk Mendukung Kecakapan Abad 21. De Fermat : Jurnal Pendidikan Matematika, 1(1), 31-38. https://doi.org/10.36277/defermat.v1i1.14

Yudabangsa, A. (2020). Pengembangan Kesadaran Keberagamaan dan Pembentukan Karakter Siswa Melalui Pembiasaan Shalat Dhuha'. Attractive : Innovative Education Journal, 2(1), 117. https://doi.org/10.51278/aj.v2i1.30 